\title{
常呂川における地形と植生による 土砂輸送への影響 \\ FIELD SURVEY ON BAR FORMATION PROCESS \\ AT THE MIDDLE REACH OF TOKORO RIVER
}

\author{
佐々木章允 ${ }^{1} \cdot$ 渡邊康玄 $^{2}$ \\ Akiyoshi SASAKI, Yasuharu WATANABE \\ 1 学生会員 北見工業大学大学院 工学研究科土木開発工学専攻 ( $\bar{T}$ 090-8507 北海道北見市公園町 165 番地) \\ 2 正会員 北見工業大学教授 工学部社会環境工学科 ( $\mathrm{T}$ 090-8507 北海道北見市公園町 165 番地)
}

\begin{abstract}
The aim of this study is to clarify the influence of the riparian forest to the sediment transport process and bar formation. The Tokoro river is selected for this study because the large amount of fine material from cultivated fields flows into the river during flood. The invasion of trees on bars and the growth of bars with bank erosion are observed at the Tokoro River. The field surveys were conducted at 2009 and 2010 to understand an influence of vegetation to the sediment transport and a relationship between growth of vegetation and bar form. The results of surveys show that the vegetation strongly influences to the fine material transportation during flood and bar shape. In addition, reproducibility of field survey was confirmed by using a numeric calculation method.
\end{abstract}

Key Words: $\quad$ bars, riparian forest, sediment transport, flood, vegetation, Tokoro river

1.はじめに

北海道東部に位置する常呂川では流域の多くが畑作 を中心とした農地によって占められており1)，洪水時 に輸送される土砂全体の内, 農地から流出する土砂の割 合は極めて高いと考えられている．洪水時に流出する 土砂量か増加した場合，畑作地帯への影響だけでなく， 土砂堆積による下流域で被害の拡大, 自然景観や生態 系への影響も考えられる. 常呂川における土砂管理を 考える上で, 農地からの土砂輸送過程を明らかにする ことは必要不可欠なものとなっている . また, 河道内に 繁茂する河畔林は洪水時に大量の土砂を捕捉するとと もに, 砂州の固定化を促進し, みお筋の固定化を引き 起こすことが近年明らかとなっている ${ }^{2)}$.さらに，砂州 の固定化に伴う対岸の河岸浸食も誘発されることが想 定され，これらの土砂輸送過程への影響を明確にする ことは，河道管理上も極めて重要な事項となっている． 本研究では河畔林の土砂捕捉機能と土砂輸送過程に 与える影響を，常呂川中流域における砂州上に河畔林 が存在するとともに, 砂州の固定化に伴う対岸の河岸 浸食が生じている区間 (河口から $15.8 \mathrm{~km}$ 地点左岸砂 州, 図-1)において, 既往の出水と砂州を含む河床高の 変化との関係を考察し, 土砂輸送過程における河道内 の地形や河畔林が与える影響を明確にすることを目的 とした .

\section{2. 研究概要}

本研究を行うにあたり，常呂川の既往の出水を把握 するため, 過去 35 年 (昭和 50 年〜平成 22 年 8 月) の

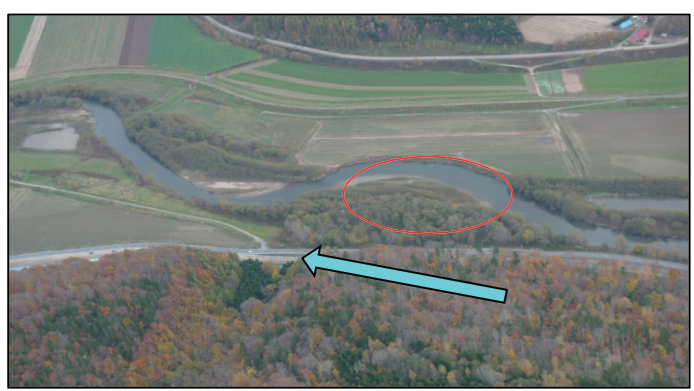

図-1 常呂川現地調査箇所

日流量データ ${ }^{3)}$ から流量時系列グラフを作成した . ま た，過去の横断データを比較することにより，河床高 や河道内の地形变化を把握し, 航空写真から常呂川中 流域における河畔林生育状況の時系列変化を把握した . 光の後, 現在の砂州地形, 砂州上の樹木の繁茂状況や 樹齢の解析，堆積した土砂の粒径分布の把握を行うた め, 平成 21,22 年に現地調査を行い, 既往の出水との関 連性を検証した .さらに , 河川シミュレーションソフ 卜,RIC-Nays ${ }^{4)}$ を使用し, 平成 21 年から 22 年までの地 形変化及び土砂堆積状況を用いて，モデルの再現性を 確認するとともに , 河畔林の有無による河床地形の違 いから, 河畔林の土砂輸送に与える影響を考察した .

\section{(1) 常呂川での既往洪水}

昭和 50 年〜平成 22 年 8 月までの過去 35 年間の常呂 川の流量時系列を図-2に示した .なお，流量データは 


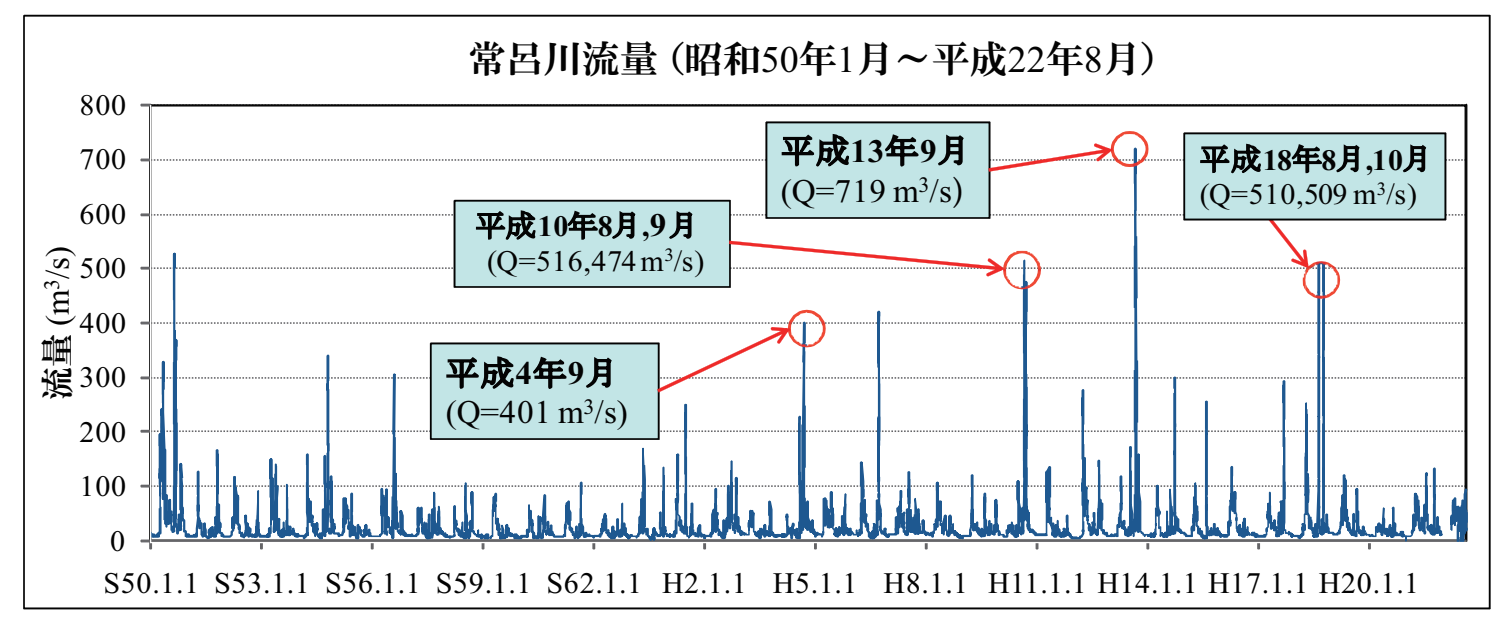

図-2 常呂川流量時系列グラフ (昭和 50 年〜平成 22 年 8 月)

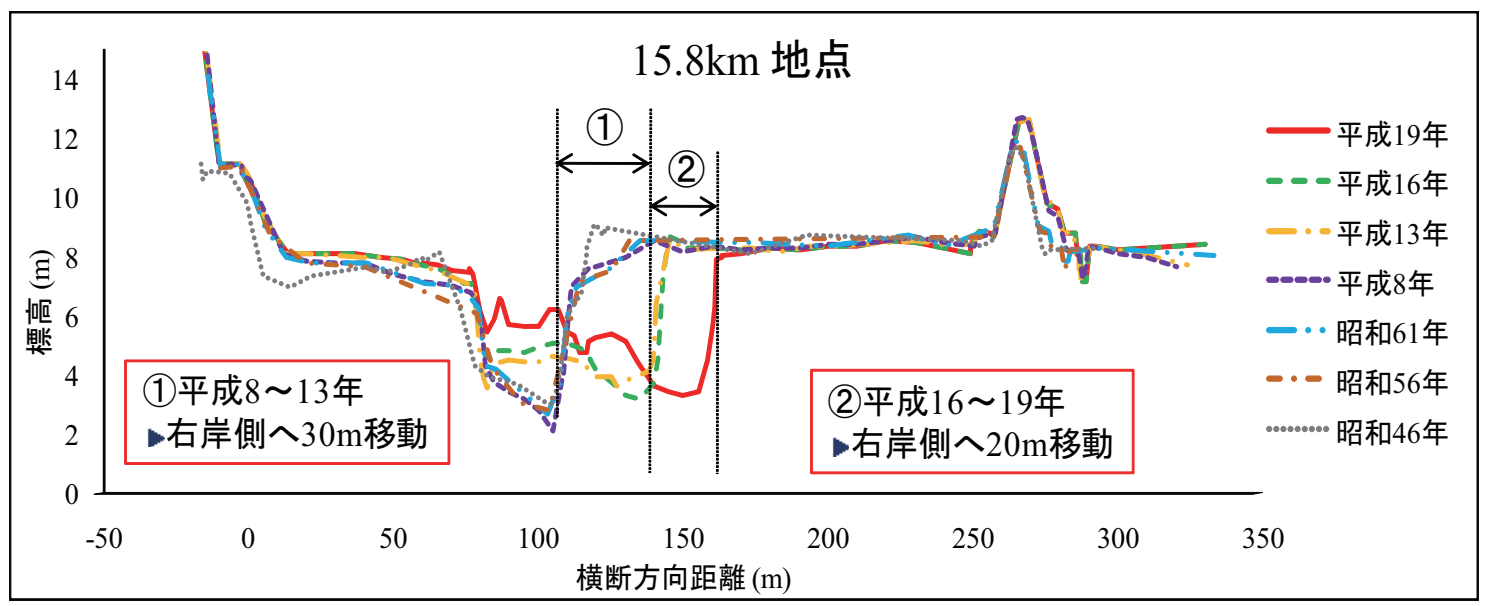

図-3 常呂川 $15.8 \mathrm{~km}$ 地点横断図

国土交通省水文水質データベース ${ }^{3)}$ の日流量年表から 常呂川北見観測所 (河口から $49.4 \mathrm{~km}$ 地点) における日流 量データを使用した . 過去の常呂川において規模の大 きな出水について図-2 に併記した . 過去 33 年間で最大 の流量を観測したのは平成 13 年 9 月 12 日 $\left(\mathrm{Q}=719 \mathrm{~m}^{3} / \mathrm{s}\right)$ である.この洪水の要因は, 秋雨前線と台風 15 号によ るもので, 流域の山地や農地から大量の土砂が流出し， 下流部の農業や漁業に大きな被害をもたらした . 流域 の汇濫面積が最も広かったものは平成 4 年 9 月の台風 17 号による洪水 $\left(\mathrm{Q}=401 \mathrm{~m}^{3} / \mathrm{s}\right)$ である.他に被害の大き かったものは, 平成 10 年 8 月の台風 4 号 $\left(\mathrm{Q}=516 \mathrm{~m}^{3} / \mathrm{s}\right)$, 9 月の台風 5 号 $\left(\mathrm{Q}=474 \mathrm{~m}^{3} / \mathrm{s}\right)$, 昭和 50 年 8 月の台風 6 号 $\left(\mathrm{Q}=526 \mathrm{~m}^{3} / \mathrm{s}\right), 9$ 月の低気圧と前線の停滞によるもの $\left(\mathrm{Q}=370 \mathrm{~m}^{3} / \mathrm{s}\right)$ である .

\section{(2) 既往洪水による横断地形の変遷}

河口から $15.8 \mathrm{~km}$ 地点の上流, 下流光れ光れ $1 \mathrm{~km}$ の範 囲において, 縦断間隔 $200 \mathrm{~m}$ 毎の横断図 ${ }^{5)}$ (昭和 45,56,61 年, 平成 8,13,16,19 年) 7 年分を用いて河道形状の変化 を把握した . 最も変化の著しい $15.8 \mathrm{~km}$ 地点の横断図と， 既往洪水の発生時期を図-3に示す.

図-3 から，平成 8 年〜 13 年と平成 16 年〜 19 年の 2 期間で地形が大きく変化していることが分かる . 図-2
に示した流量時系列グラフの大規模出水との関連性を 見ると, 昭和 50 年以降数回の規模の大きな出水におい ても大きな変化を示していなかったが, 平成 8 年〜13 年では平成 10 年 8 月, 9 月, 平成 13 年 9 月に大規模な 洪水が発生しており，水みち部分が右岸側へ約 $30 \mathrm{~m}$ 移 動する大きな地形の変化が見られる. 平成 16 年〜平成 19 年では平成 18 年 8 月, 10 月に大規模洪水が発生して おり, 地形が大きく変化し, 水みちが右岸側入約 $20 \mathrm{~m}$ 移動している.この $15.8 \mathrm{~km}$ 地点では後述する航空写真 の比較 (図-4) の結果, 平成 13 年 9 月の出水により水み ちが右岸側へ大きく移動し, 砂州が形成され, 砂州の 幅も大きくなっていることが確認された .

(3) 航空写真からの地形・ 植生の時系列変化

図-4 に示すように, 昭和 52,57 年, 平成 3,13,15,19 年 の計 6 枚の航空写真から, 植生状況や全体の地形変化 を把握した . 大きく地形か湾化しているのは平成 13 年 〜15 年の $15.8 \mathrm{~km}$ 地点 (図-4 の赤丸部分) である.この 地形の変化は図-3にも示したように, 平成 13 年 9 月の 大規模洪水によるものであると考えられ，平成 13 年の $15.8 \mathrm{~km}$ 地点には見られなかった砂州が，平成 15 年に は形成されていることが分かる.なお，この時点では， 
砂州上に植生の侵入は見られない . 平成 15 年〜 19 年で は, 平成 18 年に大規模洪水が発生しているが, $15.8 \mathrm{~km}$ 地点の砂州は大きく成長している. 平成 19 年の航空写 真では， $15.8 \mathrm{~km}$ 地点に形成された砂州上に植生が侵入 していることが分かる.この植生は, 平成 20 年に行わ れた植生調査結果 ${ }^{6)}$ より, 平成 17 年に侵入したことが 確認されている. 平成 17 年侵入の植生により砂州が固 定化されたため, 平成 18 年の 2 回の大規模洪水で砂州 か移動しなかったものと考えられる．また，平成 19 年 航空写真の $15.8 \mathrm{~km}$ 地点 (図-4 の赤丸部分) では, 右岸 側蛇行部の浸食が顕著に見られる.この浸食は現在も 進行中であり, 左岸付きの砂州の成長との関係が考え られる.この地点は, 長年, 直線的な河道であったが， 大規模洪水によって蛇行化が進行し, 弚の後, 蛇行部 に砂州の形成や砂州上への植生侵入, 蛇行部の浸食の 進行という特徵が見られる地点である。

\section{3. 現地調査}

\section{(1) 現地調査概要}

現地調査は，前述した常呂川中流域の交互砂州上に 植生が見られる，図-1に示す河口から $15.8 \mathrm{~km}$ 地点の 左岸砂州で平成 21 年及び 22 年に行った . 調査では, 砂 州地形の測量, 樹木及び河床材料の調査を行った . 地形 測量は平成 21,22 年の調査とも，縦断方向に $5 \mathrm{~m}$, 横断 方向に $1 \mathrm{~m}$ の間隔で行われた . なお, 出水中の土砂に よる埋戻し量を測定するため，レンガによる置換法で 河床高の変化の把握も行った (以降, マーカー埋設調査 と呼ぶこととする). 平成 21 年に行われた, 河床材料 の採取, 及びマーカー埋設調査は，図-5 に示す 6 地点 (A 地点から $\mathrm{F}$ 地点) で行われた．砂州の下流部の地点 を $\mathrm{A}$ 地点, 砂州の上流部の地点を $\mathrm{F}$ 地点, $\mathrm{A}$ と $\mathrm{F}$ の中間 を $\mathrm{B}$ 地点とし, $\mathrm{B}$ 地点から左岸側へ向かって, 樹高が 1 〜2m の植生が見られる箇所を $\mathrm{C}$ 地点, 同樣に $3 \sim 5 \mathrm{~m}$ の 植生が見られる箇所を $\mathrm{E}$ 地点, $\mathrm{C}$ と E の間の目立った植 生が見られない箇所を $\mathrm{D}$ 地点とした . 平成 22 年調査で は, 平成 21 年実施した調査に加え，植生の生育調査を 行った . 平成 21 年度に植生の生育調査を実施しなかっ た理由として, 同地点で平成 20 年に詳細な植生の生育 調査 ${ }^{6)}$ が行われていたため，この結果を利用すること を考えたためである.なお，地形变化や調査時の水位 の関係で $\mathrm{A}$ 地点及び $\mathrm{F}$ 地点か調査不可能であったため， $\mathrm{B}, \mathrm{C}, \mathrm{D}$ 及び $\mathrm{E} の 4$ 地点と新たに B 地点から川側へ横断 方向 $3 \mathrm{~m}$ 水際の $\mathrm{G}$ 地点で調査を行った . 砂州と光れぞ れの地点の関係を図-5に示す。

\section{(2) 現地砂州地形調查}

測量データから平成 21 年及び 22 年における $2 つ の ~$ 砂州コンター図と, 平成 21 年調査時から平成 22 年調 査時までの変化量のコンター图を作成し, 1 年間での砂 州地形の変化や植生の有無による地形の特性を把握し た．図-5に示すコンター図において，平成 21 年の B 地点の高さを基準高 $(0 \mathrm{~m})$ とし, 基準高からの高低差を
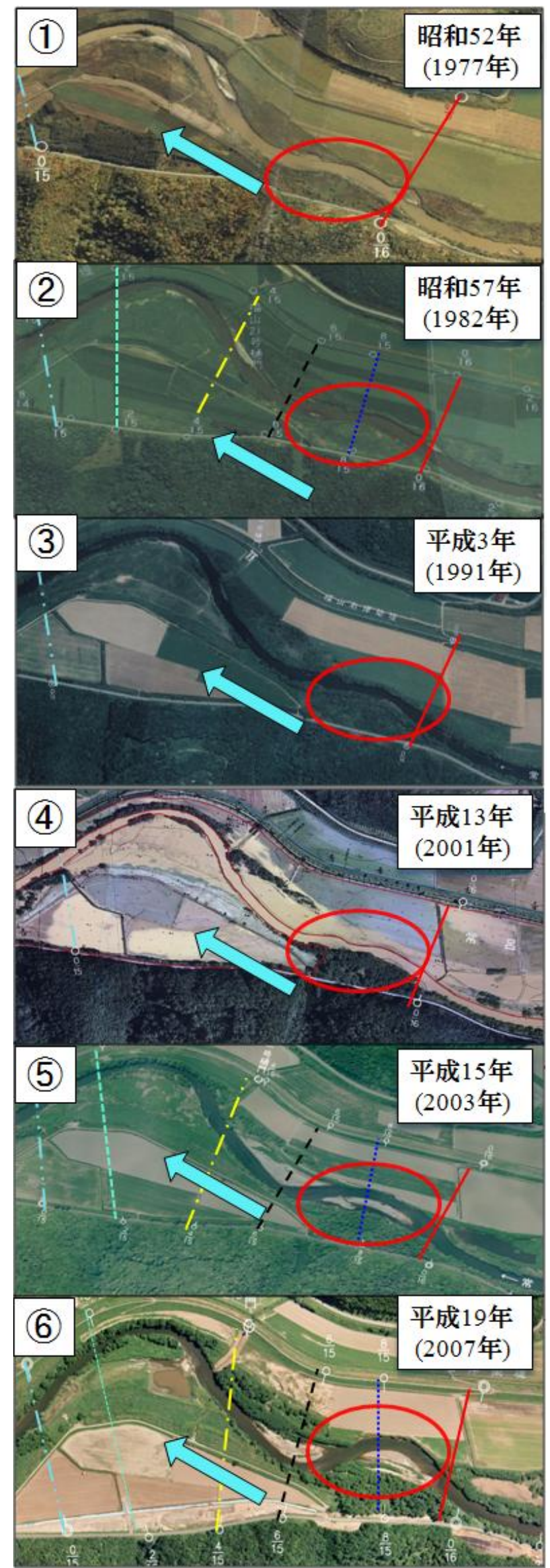

図-4 常呂川 航空写真 経年变化 (北海道開発局網走開発建設 部 提供の写真に加筆) 

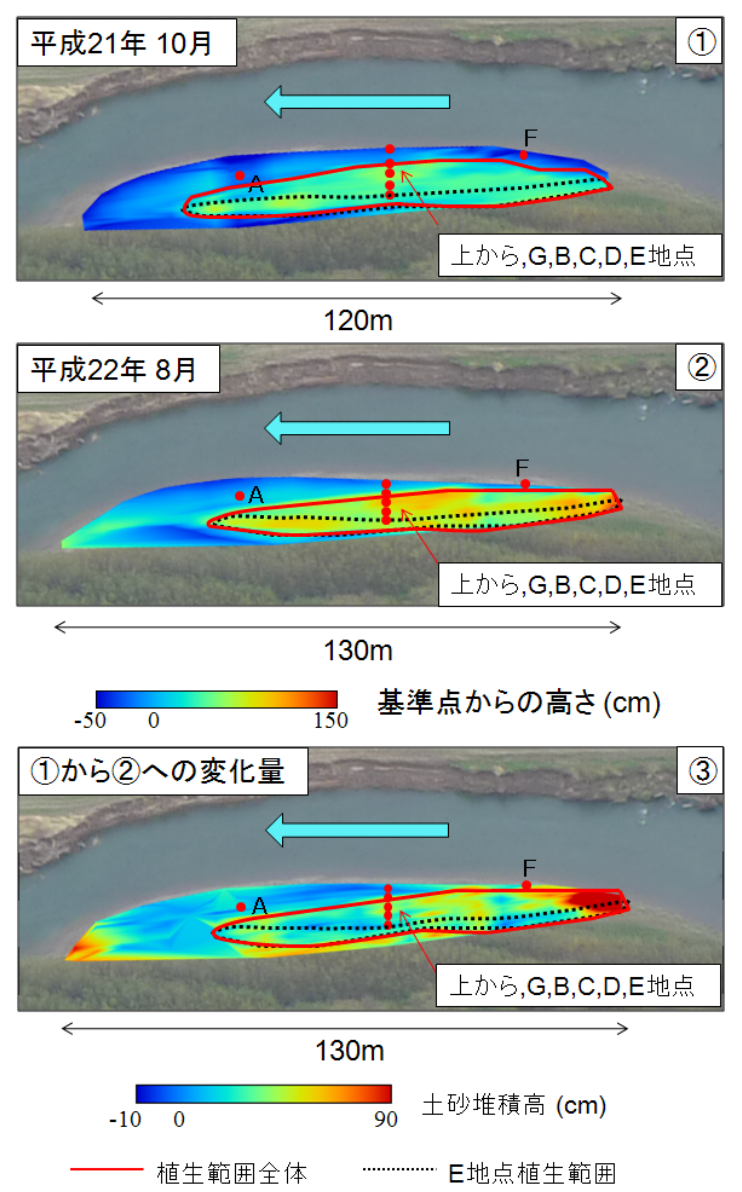

図-5 調査砂州詳細と測量結果 上:平成 21 年 中:平成 22 年 下:標高変化量

赤〜青のカラーで示した . 赤は相対的に高い場所，青 は低い場所を表している. 平成 21 年,22 年に共通して, 砂州の中央部の高さが高くなっている. 平成 21〜22 年 の 1 年間の変化を見ると, 砂州のほぼ全域で土砂が堆 積し高くなっている.特に堆積が顕著な箇所は，砂州 中央部の植生が存在する箇所 (図-5 の赤線内) と, 砂州 の上下流端である . 植生の存在する箇所では $50 \mathrm{~cm}$, 砂 州の上流側で $100 \mathrm{~cm}$ の堆積が見られる .

\section{(3) 砂州上の樹木解析}

平成 22 年の調査の際, A,B,F,G 地点は植生が全く存 在せず, D地点は丈の低い草本類は存在するものの, ヤ ナギ等の樹木が見られなかったため, C,E 地点以外での 樹木調査は行わないこととした .このため, 平成 22 年 の樹木調査は砂州上の C,E 地点でのみ行った . 調査で は C,E 地点付近に縦 $2 \mathrm{~m} \times$ 横 $2 \mathrm{~m}$ の正方形を作成し, 光 の正方形内の樹木の樹種, 樹高, 樹径, 本数, 樹齡を把握 した. 平成 22 年の現地調査結果及び平成 20 年に行わ れた植生調査 ${ }^{6}$ のデータを用い，樹木の生長 . C 地点, $\mathrm{E}$ 地点光れ光れにおける解析結果を表-1に示した。表-1 より，平成 22 年調査時における $\mathrm{C}$ 地点の樹木の樹齢 は 2 年, $\mathrm{E}$ 地点は 5 年となり, $\mathrm{C}$ 地点は平成 20 年, $\mathrm{E}$ 地 点は平成 17 年に砂州上に植生が侵入したものと判断さ れる.E地点の植生は大規模洪水が発生した平成 18 年
表-1 樹木解析結果 C 地点 (上),E 地点 (下)

\begin{tabular}{|c|c|c|c|c|}
\hline $\mathrm{C}$ 地点 & 樹種 & $\begin{array}{c}\text { 樹高 } \\
(\mathrm{cm})\end{array}$ & $\begin{array}{c}\text { 直径 } \\
(\mathrm{cm})\end{array}$ & $\begin{array}{c}\text { 樹齢 } \\
(\text { 年 })\end{array}$ \\
\hline $\mathrm{H} 20$ 年冬 & ヤナギ & 27 & 0.3 & 0 \\
\hline $\mathrm{H} 22$ 年夏 & ヤナギ & 218.1 & 1.2 & 2 \\
\hline
\end{tabular}

\begin{tabular}{|c|c|c|c|c|}
\hline E地点 & 樹種 & $\begin{array}{c}\text { 樹高 } \\
(\mathrm{cm})\end{array}$ & $\begin{array}{c}\text { 直径 } \\
(\mathrm{cm})\end{array}$ & $\begin{array}{c}\text { 樹齢 } \\
(\text { 年 })\end{array}$ \\
\hline $\mathrm{H} 20$ 年冬 & ヤナギ & 306 & 2.3 & 3 \\
\hline $\mathrm{H} 22$ 年夏 & ヤナギ & 385.3 & 3.3 & 5 \\
\hline
\end{tabular}

以前の平成 17 年に侵入していることから， $\mathrm{E}$ 地点の植 生 (図-5 の黑点線内) によって砂州が固定化され, 平成 18 年洪水の際には砂州の大きな变化が無かったとも考 えられる．また，D地点のヤナギ等の樹木が存在しな い䇢所は，砂州上に洪水時に形成されたものと思われ る $\mathrm{D}$ 地点を通る縦断方向の水みちが見られ， C,E 地点 と比較すると高さが最大で約 $30 \mathrm{~cm}$ 低くなっている .

\section{（4）砂州上の土砂堆積·洗掘調査}

平成 21 年から 22 年までの 1 年間の出水による砂州上 の土砂輸送状況を把握するため, 樹木, 土砂採取と同樣 に砂州上の A,B,C,D,E,F の計 6 地点 (図-5) でマーカー 埋設調査を行った。調査手法は, 縦 $50 \mathrm{~cm} \times$ 横 $50 \mathrm{~cm}$, 深さ $50 \mathrm{~cm}$ の穴を掘り，土砂堆積や洗掘状況を明確に するため，レンガを細かく砕いたものをマーカーとし て土砂と混合させ埋設した .マーカーの上へ土砂が堆 積した場合は关の高さを測定し，埋設地点が洗掘を受 けた場合は残ったマーカーの高さを測定し，弚れぞれ の地点の土砂輸送状況を把握した . 調査を行った結果， B,C,D,E 地点では光れ洪水中の浸食は認められず $14 \mathrm{~cm}, 23 \mathrm{~cm}, 20 \mathrm{~cm}, 22 \mathrm{~cm}$ の堆積となった . 植生の存在し ない B 地点と光の他の C,D,E 地点では, 土砂堆積高に 大きく差が見られ，樹木が多く繁茂する C,E 地点で最 も土砂が堆積するという結果を得た .

\section{(5) 砂州上の土砂特性}

砂州上の土砂の特性を把握するため, 平成 21 年は A,B,C,D,E,F地点, 平成 22 年は B,C,D,E,G 地点で土砂 採取を行い, 土砂の粒径を把握した。なお，マーカー 埋設調査結果及び測量結果から，平成 22 年の B,C,D,E 地点では平成 21 年調査時点から大きく土砂が堆積した と判断されたため, 地表面から $10 \mathrm{~cm}$ までの厚さの層 (上層) と，光の下 $10 \mathrm{~cm}$ の厚さの層 (下層) の 2 層で土 砂採取を行った．図-6に粒度試験を行った結果を示す．

図-6より，1 年間で明確な変化か現れたのは D 地点 である. 平成 21 年では植生が存在せず粒径の粗い土砂 が多く見られたが, 平成 22 年の D地点では丈の低い草 

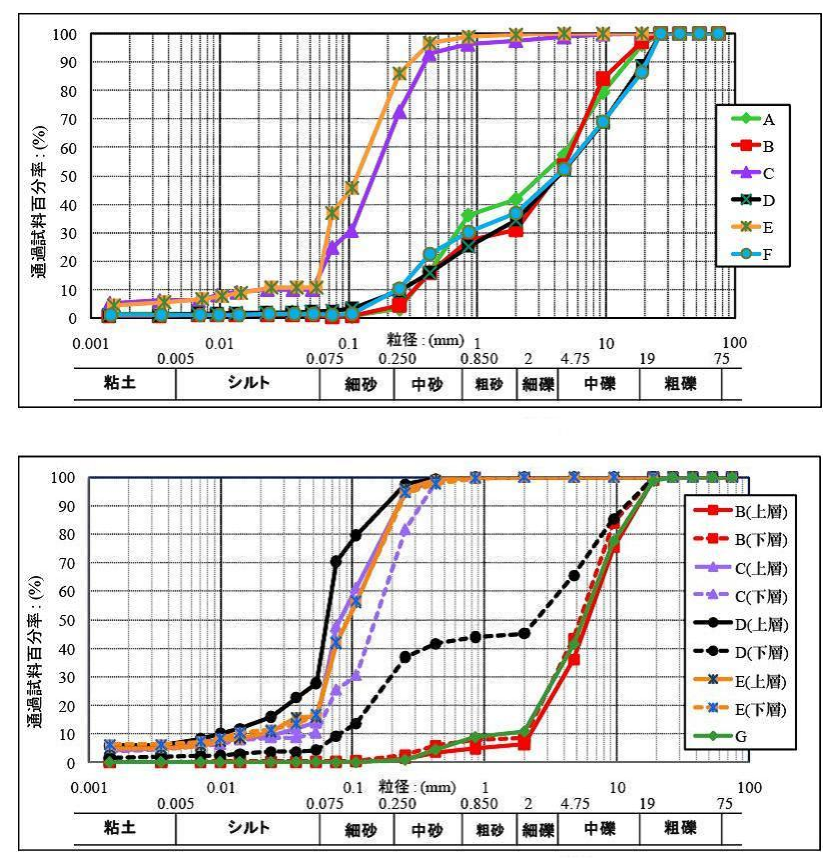

図-6 粒径加積曲線 上:平成 21 年下:平成 22 年

本類が存在し，細かな土砂を捕捉したため上層は C,E 地点と同樣の細かな粒径を多く含む粒径分布となった 。 $\mathrm{D}$ 地点下層は細かな土砂の堆積の影響により，細砂等 の細かな土砂と砂磁等の粗い土砂が混合する層となっ ている. 光の他, 平成 21 年の $\mathrm{C}, \mathrm{E}$ 地点, 平成 22 年の $\mathrm{E}$ 地点 (上, 下層), $\mathrm{D}$ 地点 (上層), $\mathrm{C}$ 地点 (上,下層) は, 細砂 を最も多く含む粒径の細かな土砂が堆積する地点であ り, 平成 21 年から 22 年までは C,E 地点の粒径分布に 大きな変化見られない. 平成 21 年の $\mathrm{A}, \mathrm{B}, \mathrm{D}, \mathrm{F}$ 地点, 平 成 22 年の $\mathrm{B}$ 地点 (上, 下層), $\mathrm{G}$ 地点では粗砂や中碟を多 く含む粒径分布となっている. 特に B 地点では 1 年間 で, 中砂や砂磁の割合が減少し, 粗砂や中礫の割合が 増加している．このことから，植生の存在の有無によ り河床材料の変化の傾向が大きく異なることが分かる．

\section{(6) まとめ}

以上のことから，現在の $15.8 \mathrm{~km}$ 地点の砂州は平成 13 年 9 月の洪水以降に上流からの土砂輸送により形成さ れたものであり，平成 15 年までの出水により砂州の原 型が形成されたと考えられる . 同時に上流からの細か い土砂か現在の C,E 地点付近に堆積し, 弚の後出水が 無かった平成 17 年に $\mathrm{E}$ 地点で確認された植生が侵入し 成長したものと考えられる. 図-7に示すように平成 17 年の植生侵入後, 平成 18 年 8 月及び 10 月の洪水によ り水みちが横断的に移動し, 洪水後に砂州上に残され た樹木により上流から輸送される土砂か捕捉されやす くなったと考えられる. 平成 21 年から 22 年の 1 年間 では, 横断的な土砂堆積高の大きな違いは見られなかっ た . 図-8 に平成 16 年〜22 年までの高さの経年変化を 地点別 (B,C,D,E 地点) に示した .

$\mathrm{C}, \mathrm{E}$ 地点に生育する植生の大半はヤナギである . 一

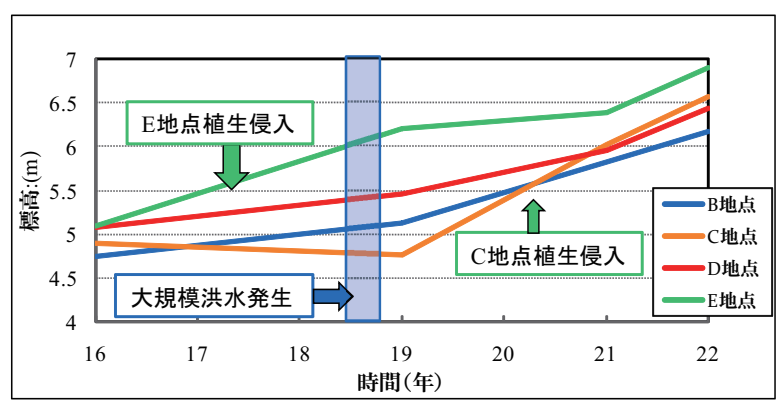

図-8 B E 地点の高さの経年変化

般にヤナギは，個体間競争により時の経過とともに淘 汰され，個体数が減少して密度が低くなる ${ }^{6)}$ と言われ ていることから，C,E 地点のヤナギは砂州への侵入直 後は樹高が低いか密度は高く, 光の後, 現在の密度ま で低下したものと考えられる，一方，図-8に示すよう に，C,E 地点の標高はヤナギの侵入直後に大きく上昇 していることが分かる.すなわち, 植生侵入直後の植 生密度が高い時期には, 上流からの土砂が多く堆積す るものと判断される. 図-6より, 平成 21 年から 22 年 の 1 年間に堆積した土砂の大半は, 粒径の細かな土砂 であることが確認できる .

平成 22 年に植生が初めて確認された D地点では, 地 表面から根の数 $\mathrm{cm}$ 下まて細かな粒径の土砂か堆積して おり, 平成 21 年調査時の地表面に土砂が堆積した後, 植生が侵入したものと考えられる . 以上のことを踏ま えて, 土砂堆積と植生の関係を見ると, 砂磁で構成さ れていた砂州に出水等で細かな土砂が堆積し, 植生が 侵入する .さらに, 侵入した植生の影響で細かな土砂 がより堆積されやすい状態となり，砂州が固定化され ていくものと考えられる .

また, 調査地点 (15.8km 地点) は長年, 直線的な河道 形状であったが平成 13 年 9 月の大規模出水を機に右岸 が浸食され始めたと判断することができる．この右岸 浸食と左岸砂州の形成は, 密接に関係していると考え られ, 直線河道から蛇行河道への変遷, 砂州形成, 植 生の侵入，植生による土砂捕捉という流れを考える上 で極めて重要である .

\section{RIC-Nays によるシミュレーション}

\section{(1) 計算概要}

現地調査を行い，この結果，植生の侵入が砂州の発 達に大きく関与していることか確認された . しかし, 植 生が侵入しなかった場合との比較は行うことが不可能 である.このことから, 数値計算手法を用いて, 植生が 侵入しなかった場合との比較を試みることとした . 計 算は, 河川シミュレーションソフト,RIC-Nays 及び 2 次 元河床変動解析プログラム ${ }^{4)}$ を用いた . 植生内への流 れについては付加的な抵抗を与え, 河床変動は掃流砂 と浮遊砂の両方を考慮し, 植生内への土砂堆積につい ても，一般の河床変動 ${ }^{4)}$ と同樣としている． 


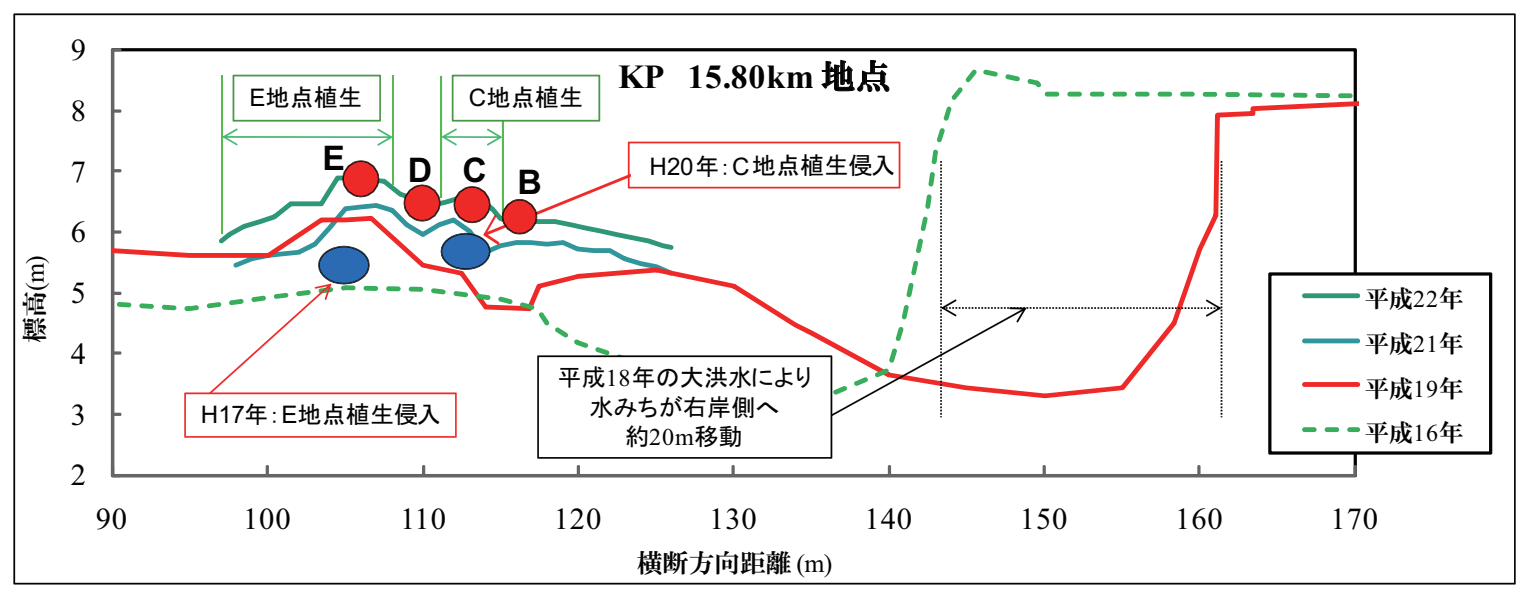

図-7 横断図によるまとめ $(15.8 \mathrm{~km}$ 地点 $)$
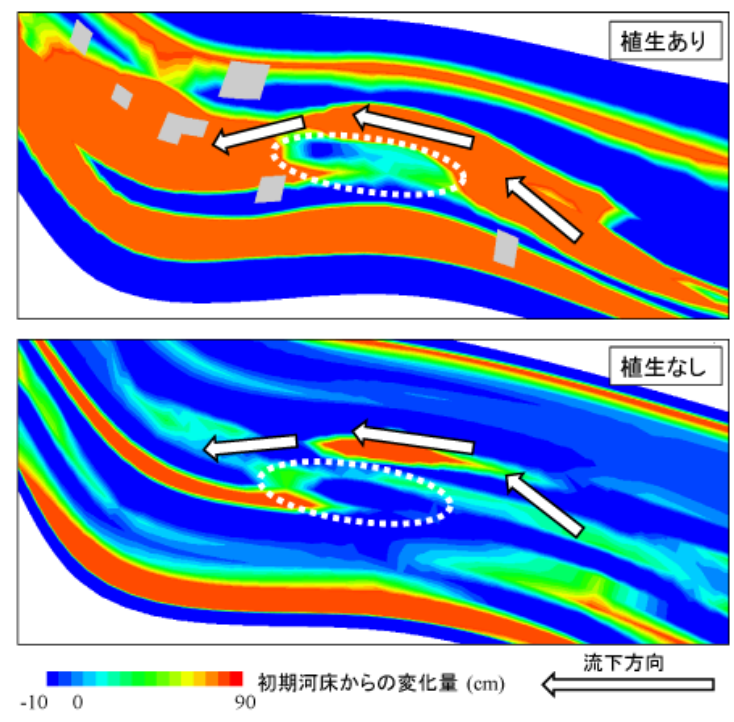

図-9 $15.8 \mathrm{~km}$ 地点付近 シミュレーション結果 上:植生あり 下:植生なし

シミュレーションを行う区間は, 水位・流量観測所 がある $10.8 \mathrm{~km}$ 地点 (上川沿) から $19.0 \mathrm{~km}$ 地点 (太茶苗) とした . 河床地形データは, 最新である平成 19 年の横 断データを使用し，流量は上流端である $10.8 \mathrm{~km}$ 地点 (上川沿), 水位は下流端である $19.0 \mathrm{~km}$ 地点 (太茶苗) の データを使用し, 流量, 水位は平成 21 年 11 月, 平成 22 年 4 月から 8 月末までの 6 カ月間の日流量データを用 いた (平成 21 年 12 月から平成 22 年 3 月末までの 4 カ 月間は河川結永のため省略).

\section{(2) 計算結果}

図-9 に初期河床からの変化量を示す. 図-9の上は航 空写真及び現地調査から河道内の植生状況を把握し, 植 生を配置したものであり，下は植生なしの場合である． 図-9に示すカラーバーは, 図-5に示した標高変化量と 比較を行うために, 最大值 $90 \mathrm{~cm}$, 最小値 $-10 \mathrm{~cm}$ とした . 図-5 の白点線内が $15.8 \mathrm{~km}$ 地点の左岸砂州である.2つ の結果を比較すると植生あり (図-9, 上) の場合では, 砂 州の上流部を中心に砂州全体に土砂が堆積する結果と
なった . 植生なし (図-9,下)の場合では, 砂州上に僅か な土砂堆積が見られる程度であった．以上の結果から， 砂州上に植生が繁茂する場合は, 土砂が堆積しやすく なり, 現地調査箇所の土砂堆積状況を再現することが できた .

\section{5. おわりに}

本研究は常呂川河道内の植生が土砂輸送へどのよう な影響を及ぼすかを明確にするために行われた . 兴の 結果, 過去のデータ解析や現在の地形を調査すること により, 現在の砂州の形成過程や植生による土砂捕捉 状況を明確にすることができた . 今後は, 大規模出水が 発生した場合の右岸浸食, 左岸砂州形状の变化, 植生状 況, 土砂輸送状況調査を継続的に行っていく必要がある.

謝辞：本研究は平成 21 年度科学研究費補助金 (基盤研 究 B, 代表:渡邊康玄, 課題番号:20360224) の助成を受け て行われた .また, 北海道開発局網走開発建設部より 常呂川横断データ並びに常呂川航空写真データの提供 をして頂いた .ここに記して謝意を表します。

\section{参考文献}

1) 北海道開発局 網走開発建設部 常呂川水系河川整備計画 常呂川水系流域及び河川の概要 7. 河川空間への利用状況 2007-2009.

2) 辻本哲郎：植生を伴う流れの水理, 1991 年度 (第 27 回) 水工学に関する夏期研修会講義集 1991.

3）国土交通省 水情報国土データ管理センター：水文水質 データベース, http://www1.river.go.jp/

4) 財団法人北海道河川防災研究センター: 河川 シミュレーション支援ソフトＲIC-Nays, http://iric.org/nays/ja/index.html

5) 北海道開発局 網走開発建設部，常呂川定期横断測量

6) 株式会社 森林環境リアライズ: 常呂川河道内樹木調査作 業 常呂川河道内樹木データ整理作業 報告書 2008 .

7) 北海道開発局 網走開発建設部 常呂川流域懇談会からの提 言 2003

8）社団法人 地盤工学会 土質試験 基本と手引き，2001. 